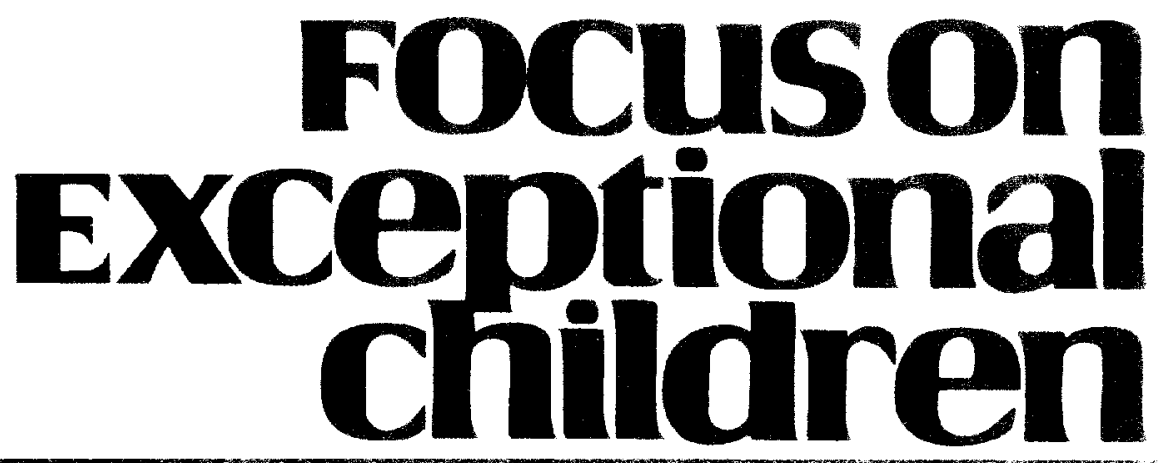

\title{
Best Practices for Teaching Mathematics to Secondary Students with Special Needs
}

\author{
Paula Maccini and Joseph Calvin Gagnon
}

Having all students achieve in mathematics is considered a national priority, as indicated in the Goals 2000: Educate America Act (PL 103-227). Mathematics is the gatekeeper to a number of opportunities for occupational and educational advancement (Jetter, 1993). Further, more state and district requirements (e.g., Maryland, Virginia) are including high-school math assessments that students have to pass to receive diplomas.

Though math is vital to students' future, many students have difficulty with it. According to the Third International Mathematics and Science Study (TIMSS) (International Association for the Evaluation of Educational Achievement, 1996), American eighth-grade students score significantly below the international average in math and outperform only seven other nations (Bernstein, 1997). Further, American 12th graders have an overall math average significantly below the international average.

Discrepancies in the nature of classroom activities across countries may help to explain student performances. U.S. students spend $96 \%$ of their seatwork time practicing routine procedures, whereas Japanese students engage in this type of exercise only $41 \%$ of their seatwork time (Bernstein, 1997). In addition, Japanese students work on problems that require the invention of new solutions, proofs, or creative procedures $44 \%$ of the time, compared to U.S. students, who engage in similar activities less than $1 \%$.

In the past, reforms such as back to the basics and individualized instructional programs have attempted to address the issue of how to improve students' mathematics performance. More recently, the National Council of Teachers of Mathematics (NCTM, 1989, 1991, 1995) has outlined changes in curricular, assessment, and teaching practices that emphasize complex math tasks requiring problem solving and mathematical reasoning skills and deemphasize rote computation and memorization tasks.

Paula Maccini. PhD. And Joseph Calvin Gagnon, M.A. are affiliated with the University of Maryland. College Park.

(1) Love Publishing Company, 2000 
This new vision in math education is outlined in the Curriculum and Evaluation Standards for School Mathematics (NCTM, 1989) and includes 13-14 focus statements per grade section (i.e., K-4, 5-8, 9-12, evaluation). These statements are commonly referred to as "Standards" as they represent the philosophy for teaching and assessing mathematics. The three grade sections share four standards for teaching math concepts or skills

1. Math as problem solving (e.g., incorporating real-life math applications and utilizing problem-solving strategies)

2. Math as communication (i.e., writing, explaining, discussing math ideas)

3. Math as reasoning (i.e., incorporating logical reasoning into math areas)

4. Math connections (i.e., relating math concepts to other math tasks and conceptual understanding, and to other content areas/real-life situations).

\section{Focuson
Exceptional
children}

ISSN $0015-511 \mathrm{X}$ FOCLS ON EXCEPTIONAL CHILDREN (USPS 203-360) is published monthly except June. July. and August as a service to teachers. special educators, curriculum specialists, administrators, and those concerned with the special education of exceptional children. This publication is annotated and indexed by the ERIC Clearinghouse on Handicapped and Gifted children for publication in the monthly Current Index to Joumals in Education (CIJE) and the quarterly index, Exceptional Children Education Resources (ECER). The full text of Focus on Exceptional Children is also available in the electronic versions of the Education Index. It is also available in microfilm from Xerox Lniversity Microfilms. Ann Arbor. MI. Subscription rates: Individual. \$30 per year; institutions. $\$ 40$ per year. Copyright $\$ 2000$. Love Publishing Company. All rights reserved. Reproduction in whole or part without written permission is prohibited. Printed in the United States of America. Periodicals postage is paid at Denver, Colorado. POSTMASTER: Send address changes to:

Love Publishing Company

Executive and Editorial Office

P.O. Box 22.353

Denver. Colorado 80222

Telephone (303) 221-7333

Karen Harris

University of Maryland
Thomas Skrtic University of Kansas

James Shriner

$$
\text { University of Illinois }
$$

Stanley F. Love Publisher
Thomas S. Love Associate Editor
The five goals or outcomes that encompass the "spirit" of the Standards include the ability for students to (NCTM. 1989):

- become better problem solvers (i.e., including math tasks that require problem-solving and related strategies)

- learn to reason mathematically (i.e.. having students explain or defend their thinking)

- learn to value mathematics (i.e., understanding why math is important to real-world situations)

- become more confident in their mathematical ability (i.e., developing students' self-confidence with math)

- learn to communicate mathematically (e.g.. learning to read, write, and discuss math ideas)

The suggestions that encompass these goals are guided by the philosophy of constructivism, in which students' "construct" their own knowledge via active engagement in learning activities and assimilating new knowledge with existing information (Van De Walle, 1994). For the secondary math classroom, this includes more emphasis on tasks that require mathematical reasoning and problem solving.

The recommendations for change may be challenging for teachers and secondary students with learning disabilities (LD) and emotional/behavioral disorders (ED) because of: (a) learner characteristics, (b) teacher practices and awareness, and (c) clarity and research issues. For example, many students, particularly students with LD and ED, fall further behind in their academic performance despite the efforts of NCTM to reach "all students." These students are at-risk for school failure as many experience low levels of math performance and have social and behavioral issues that impede their learning. These two disability categories account for more than $65 \%$ of students labeled in special education. Given this high representation of students with ED and LD. it is alarming that only $12 \%$ of these students take advanced math courses (e.g., algebra, geometry, calculus, trigonometry) (Wagner \& Blackorby, 1996).

While the results of these two groups of students are not reported separately within the TIMSS and NAEP, other research provides data through which their levels of success may be evaluated. For example, over one-fourth of students labeled LD have been identified specifically due to a discrepancy between math aptitude and performance (Brian. Bay, Lopez-Reyna, \& Donahue, 1991). On average, adolescents with LD function 2.7 grade levels below their nonlabeled peers (Wagner, 1995). Specifically in math, secondary teachers have noted that many of their students experience difficulty in mathematics (McLeod \& Armstrong, 1982). Further, Cawley and Miller (1989) determined that adolescents with $L D$ have difficulty with problem application and 
generally perform at the 5th grade level. Additionally, many secondary students with LD experience difficulties with a range of mathematics tasks, including basic skills (Algozzine, O'Shea, Crews, \& Stoddard, 1987) and higherlevel skills/concepts and problem solving (Huntington, 1994; Hutchinson, 1993; Maccini \& Hughes, in press; Maccini \& Ruhl, in press).

Many secondary students with ED also share a common set of learner characteristics that negatively affect their academic success including: (a) a lack of persistence; (b) anxiety; and (c) problems with attention (Bos \& Vaughn, 1994). Although variation in the operational definition of these characteristics limits generalization, their importance becomes evident in light of the rigorous goals of the Standards (i.e., perseverance with mathematical tasks, confidence in using math, and appreciation of mathematics application). It is not surprising, then, that students with ED are typically 1.8 grade levels behind their nonlabeled peers, and of these students, more than half do not receive a high school diploma (Wagner, 1995).

In addition to learner characteristics that influence successful performance in mathematics, Fitzmaurice (1980) surveyed special-education teachers and determined that adequate instruction in helping students with LD complete open-ended problem-solving tasks may be a challenge. Specifically, these respondents noted more competence with their own computation skills than conceptual mathematical tasks. Too. Heshusius (1991) noted that instructional practices common in special education classrooms focus narrowly on computational tasks rather than higher-order problem-solving activities that are in line with the goals of the Standards. Further, it has been suggested that many special education teachers are unfamiliar with the national Standards for teaching mathematics and receive little support for increased awareness and training of these Standards (Goodrich \& Stern, 1995).

Researchers in the field of special education also have equivocal views regarding the Standards and students with disabilities. For example, Hofmeister (1993), Mercer, Harris, and Miller (1993), and Rivera (1993) have noted concerns with the "vagueness" of the Standards and the lack of a clear focus for teaching, as well as a lack of empirical validation that addresses the unique characteristics of students with disabilities (Chard \& Kameenui, 1995). Nevertheless, these researchers and many others in the field of special education (Mercer, Jordan, \& Miller, 1996; Thornton, Langrall, \& Jones, 1997) recognize the importance of embedding mathematics in problem-solving situations and expanding the content traditionally underrepresented in math programs (e.g., statistics, estimation).

The challenge is clear for general and special educators who struggle to accommodate individual differences in light of these Standards. This is a result, in part, to the national trend toward inclusionary practices in which more students with disabilities are being educated in general education classes and are exposed to the curricula their nondisabled peers receive. Given that school districts are redesigning their math curricula to reflect the NCTM goals (Parmar \& Cawley, 1995), teachers must be informed of validated practices and supports necessary for helping these students in math relative to the goals of the Standards.

Further, as many students with LD and ED experience difficulty with skills that relate to the goals of the Standards (e.g., problem solving, reasoning), teachers must be aware of instructional interventions to accommodate learner characteristics. Thus, the purpose of this review is threefold: (a) to relate results of a survey that investigates the instructional supports and adaptations that special and general education teachers perceive as effective for teaching math to secondary students with LD and ED in light of the Standards: (b) to provide examples and support in light of practices that have been found to be effective with this population, and (c) to provide recommendations for future practice.

To address the first goal, a representative sample of secondary general and special education teachers in Maryland were contacted via a mail survey and answered open-ended responses to determine their ideas relative to the goals of the NCTM Standards and students with LD and ED (see Maccini \& Gagnon, 2000; Gagnon \& Maccini, 2000 for a full description of the study). The open-ended responses were coded for major themes and then analyzed relative to the frequency of the ideas perceived as effective practices for secondary students with LD and ED. In addition, the authors conducted a comprehensive review of the literature of validated teaching practices and related background information targeting math interventions for secondary students with LD and ED. The following discussion covers these findings: (a) advantages of the NCTM Standards; (b) specific instructional approaches, (c) typical adaptations and provisions based on students' IEP; and (d) teaching methods to improve successful implementation of the Standards with students who have LD and ED.

\section{ADVANTAGES OF THE NCTM STANDARDS}

General and special education teachers in the current study identified three specific advantages of implementing the NCTM standards with students labeled ED and LD. According to these participants, the Standards:

- promote hands-on learning (i.e., use of manipulatives to promote conceptual understanding versus rote memorization)

- support "equal opportunity" between general and special education students (i.e., share the same curriculum) 
- emphasize a more rigorous mathematics program encompassing higher-order reasoning and critical thinking skills.

Teachers also indicated that activities based on the goals of the Standards address the connection between mathematics and real-world applications and connections to other subject areas specifically for students with LD. For example, respondents noted the importance of incorporating hands-on learning activities ("Many students with disabilities have not internalized concepts at a concrete level, so that part of the Standards is very helpful"), equal opportunities among general and special education students ("Implementation of these Standards to LD students puts them on equal footing with their peers, and it increases their math abilities and knowledge"), a more rigorous math program ("Ensures that they are given the opportunity of experiencing higher level math beyond functional 'basics ".), and real world connections ("Math concepts are connected and make sense to students who usually don't see a purpose for high math skills"). In the discussion that follows, the advantages will be explored within the context of the remaining questions.

\section{INSTRUCTIONAL APPROACHES AND METHODS}

Teacher responses regarding specific instructional approaches or methods used to implement the goals of the NCTM Standards were categorized into 16 areas according to similarity in content. Responses were evaluated for commonalties within and between teacher categories (e.g., special education teacher, general education teachers) and student categories (e.g., LD, ED). The most prevalent responses by general and special education teachers between and across categories included: (a) effective instructional techniques; (b) use of manipulatives; and (c) real-life application.

Specifically, teachers indicated that use of manipulatives is important for implementing the goals of the NCTM Standards with students who have LD and ED (general education, $19 \%$; special education, $12 \%$ ). For example, teacher responses included general statements ("I use a lot of handson activities using dice, pattern blocks, regular blocks, spinners, and other manipulatives"); and specific recommendations for geometry or algebra, respectively ("Geometry skills and concepts are taught through manipulatives. We measure perimeter and area of our classroom, desk space, etc. Measure off a garden area in front of the school-determine space the plants need to grow before planting"; Showing simple integer problems using different color chips on overhead"). Some special education teachers noted the importance of frequency for the use of manipulative ("A lot of hands-on activities. I make sure that the lesson will be able to reach the visual and auditory learners": "Use of hands-on materials as often as possible (i.e., use of actual menus to determine sales tax, tip, trips to restaurants, etc.").

Special education teachers" most prevalent response involved effective instruction techniques for students with LD (18\%) and ED (19\%), whereas general education teachers indicated either manipulatives for students with $\mathrm{LD}$ $(19 \%)$ or cooperative grouping arrangements (16\%). Responses categorized under "effective instructional techniques" involved components found to be effective for teaching students with mild disabilities, including teacherdirected instruction, pacing, and small-group instruction. For example, one teacher noted, "I model everything constantly. I show over and over one correct way, but challenge them to develop their own way to become problem solvers." In addition, use of real-life applications was noted as the second most prevalent instructional consideration (special education, $15 \%$ ) for students with ED and the fourth instructional consideration for students with LD (special education, $11 \%$ ) or ED (general education, $11 \%$ ). Teachers noted the importance of providing real-world application to help students generalize math skills and concepts, ("Mathematical connections-I have students bring in grocery ads from at least two different stores. We then shop from the ads to prepare three meals for three days and the cost...").

In the following discussion, teacher responses are discussed further and examples from the literature are highlighted to support the three most prevalent recommendations (effective instruction techniques, manipulatives, and reallife application) for implementing the goals of the NCTM Standards. In addition, guidelines for the effective implementation of the three recommendations are included.

\section{Effective Instruction}

Research on "effective instruction" supports instructional and curricular methods that help students with disabilities and others who are considered academically at-risk. The studies involve specific curricular design variables and teaching techniques (i.e.. Direct Instruction) and general teaching methodologies (i.e., direct instruction). Specifically, Direct Instruction (DI) refers to a method of instruction that addresses both curricular design (i.e., "what" to teach) and teaching methodologies (i.e., "how" to teach) and includes six components:

1. Explicit strategy instruction (i.e., teaching a strategy that can be generalized to many examples or problems)

2. Mastery learning (i.e., having students reach a criterion before advancing to a new step)

3. Error corrections (i.e., immediate teacher correction if a student errs via prompting or repeating the fact) 
4. Fading teacher involvement as the student assumes more responsibility for learning the material

5. Wide range of examples and nonexamples to enthance generalization

6. Cumulative reviews of previously learned skills.

Certain teaching practices are also recommended, such as providing immediate feedback. using signals for individual/group responses, and monitoring student performance (Tarver, 1992). The general direct instruction method includes similar teaching methodologies that can be applied across curricular areas to promote student learning (Rosenshine \& Stevens, 1986):

1. Reviewing previously learned skills

2. Teaching content (teacher demonstration, guided practice, and independent practice)

3. Providing student feedback and monitoring student performance

4. Providing corrective feedback and review or reteaching as necessary

5. Independent student practice

6. Cumulative reviews, monthly and weekly.

Although instructional approaches advocated by the goals of the Standards support a more student-focused (i.e.. teacher as facilitator) learning environment than the more teacher-directed approaches, respondents in the current study noted ways in which the two approaches complement each other. For example, one teacher noted, "I model everything constantly. I show over and over one correct way, but also challenge them to develop their own way to become problem solvers." Similarly, general and special education teachers noted the importance of teacher modeling and pacing for teaching students with LD and ED ("I always list the objectives and NCTM Standards on the board. I always give students the rationale for studying a specific concept"; "The pace at which I teach is much slower. I use a variety of activities to teach one concept. ... I also reteach before moving on if I see a problem with the majority when I have taught a concept").

Teachers in the current study also supported the use of several components of effective instruction ("Scaffolding and modeling - making a task easier for the student by modeling a similar problem first or providing the framework for the students and having them fill in the missing details"; "DI Instruction techniques: repeat and drill and pacing; teaching until mastery; structure"; "Repetition of skills/directions"). General and special education teachers both stated the need for explicit teacher-modeling when instructing secondary students with LD, ("Being very specific-step-by-step instructions": "Giving many examples with the steps to help them solve the problems on their own").
When asked to provide specific approaches for teaching students with ED, teachers noted the importance of organizing a structured learning environment to help these students succeed, ("structured environment"; "maintain a structured (to a point) environment at all times"; "Give a lot of praise and quick correctional feedback"; Providing structure for the course and each class is the only special thing I know to do with these children"). Although a wealth of research validates components of effective instruction (Tarver, 1992). two studies in particular exemplify the effectiveness of combining principles of effective instruction with goals of the NCTM Standards.

In the first study, researchers (Kelly, Gersten, \& Carnine, 1990) investigated the effects of a math curriculum involving features of instructional design versus a basal curriculum for teaching fraction concepts to students with LD and other academically at-risk secondary students within a general education setting. The instructional design curriculum involved videodisc instruction for teaching fractional number concepts (e.g., numerator, denominator, basic fractional operations). The intervention included the following instructional design variables:

1. Discriminating among problem types (i.e., adding or multiplying fractions) and terms (i.e., numerator and denominator)

2. Separating potentially confusing math tasks, such as introducing the terms numerator and denominator during different lessons

3. Incorporating a range of problems (e.g., fractions greater than 1, unknowns on either side of the equations).

Further, the step-by-step method for teaching fractions entailed learning to translate pictorial displays of fractions into numeric equations and then receiving immediate feedback via the computer. Students then learned the rule for adding fractions involving step-by-step directions ("When you add or subtract fractions with the same denominator, first copy the denominator, then work on top ") (Kelly, Gersten, \& Carnine, 1990, p. 26). Conversely, students in the control group received basal instruction that did not include the instructional design variables. Rather, students learned skills in isolation or one skill per lesson. Potentially confusing terms were not separated (e.g., students learned the terms numerator and denominator during the same lesson), and a narrow range of examples was presented (e.g., fractions less than 1 , unknown on the right side of the equation only). As a control measure, instruction in both groups included methods of effective instruction, such as corrective feedback. guided and independent practice, and classroom management techniques. 
The researchers determined that students in both groups improved their performance as compared to pretest measures. Students in the control group, however, made more errors than students in the treatment group in discriminating between the rules for addition and multiplication of fractions, and they confused the terms numerator and denominator. Further, more than $80 \%$ of the students in the control group had difficulty analyzing fractions greater than 1 $(39.10 \%)$, whereas students in the treatment successfully analyzed a range of example problems $(93.80 \%)$. Kelley et al. (1990) stated, "Specific error patterns can arise as a direct result of aspects of the curriculum used. The range and sequence of examples used in a curriculum can have a powerful effect on student performance. When a curriculum adequately conveys a particular concept or skill, transfer to related tasks occurs more readily" (p. 28).

Moore and Carnine (1989) also studied the effect of certain curriculum design variables versus basal instruction on students' performance involving problem-solving tasks requiring ratio and proportions. Twenty-nine students, including six students with math disabilities, were assigned randomly to either the treatment group, curriculum design variables (ATCD), or the control group, basal design curriculum (ATBC). Treatment in the ATCD group included a videodisc program involving the following curriculum design features: (a) explicit strategy instruction (i.e., students were taught one strategy generalizable to various problems in a step-by-step sequence that required mastery at each step): and (b) exposure to a wide range of examples and nonexamples to belp students with discrimination (e.g. mixed sample of problems during cumulative reviews).

For example, to solve the problem, "Nine pencils cost 69 cents. How much do 21 pencils cost?" students were taught to: (a) identify the correct units of measure, (b) write the label identifying the units of measure per column, and (c) align the number quantities with the similar units of measure per column (Moore \& Carnine, 1990, p. 35). For example:

$\begin{gathered}\text { pencils } \\ \frac{9}{21}\end{gathered}=\stackrel{\text { cents }}{\underline{69}}$

Conversely, students in the ATBC group were exposed to basal instruction that did not include these variables. Rather. students learned different strategies for solving word problems, including three procedures for determining the percent of a number during one lesson. Further, students did not learn the strategies in steps, and they practiced skills in isolation from other skills learned previously. Instruction in both groups also included effective teaching components (e.g., model/demonstration, monitoring student performance via questioning, guided practice, independent practice, fast pacing, mastery learning, immediate feedback) as a control measure. As a result of the treatment, it was determined that students in both groups improved their problem-solving performance as compared to pretest measures. Students in the treatment group, however, outperformed control group students significantly on a posttest assessment and maintained higher scores on unit tests.

The goals of the NCTM Standards, evident in these studies, include:

1. Incorporating technology-based instruction into mathematics lessons

2. Utilizing pictorial displays for concept development

3. Focusing on problem-solving tasks

4. Applying strategies to problem solving tasks.

Researchers in both studies, as well as what is known about effective instruction, demonstrate the need for effective math programs to also include the following curriculum design variables when designing instruction for secondary students with disabilities:

1. Teach explicit strategy instruction within a step-bystep approach, and require mastery at each step.

2. Include effective teaching components (e.g., teacher modeling, guided practice, independent practice, corrective and positive immediate feedback, monitor student responses).

3. Use a wide range of examples and nonexamples to promote generalization.

4. Separate potentially confusing terms/skills to reduce student errors.

5. Promote discrimination practice such as cumulative reviews involving new and previously mastered material.

\section{Manipulatives and Conceptual Knowledge}

One avenue for student exploration is the use of manipulative aids in mathematics. Manipulatives are concrete objects that students can physically arrange or group to represent an array of mathematical relationships (e.g., coins, base 10 blocks, counters, toothpicks). General education and special education teachers alike indicated using specific manipulative materials when teaching secondary students with LD and ED ("I use two-colored counters (one-sided painted lima beans) to express negative and positive integers and model adding integers using zero pairs"; "I use hands-on equations where each student has a balance mat and number cubes to manipulate and demonstrate the basic rules for solving equations").

Use of these concrete aids has been determined to be an effective medium for students across grade and developmental levels, including students with disabilities (Huntington. 
1994; Maccini \& Hughes, in press; Maccini \& Ruhl, in press). For example. Huntington (1994) investigated the effects of using manipulatives and teacher-directed instruction on the algebra performance of three secondary students with LD. Students were taught relational statements requiring problem representation and problem solution (e.g., "My brother and I drove to Chicago. It was 900 miles. He drove three times as far as I did. How far did I drive?"). In this single-subject design study, students were taught via teacherdirection (i.e., teacher modeling, guided feedback, and independent practice) how to solve algebraic word problems involving relational statements and the use of the Algebra Lab Gear (Picciotto, 1993). The Algebra Lab Gear involved colored plastic tiles to represent both numeric and variable amounts during problem representation and solution.

Specifically, students advanced through three instructional stages - concrete. semiconcrete, and abstract (CSA) instruction. At the concrete phase, students were taught to manipulate the algebra tiles to represent relational statements. Once students reached a criterion of $100 \%$ over three consecutive trials, they learned to represent relational statements via pictorial representations at the semiconcrete level. After reaching criterion, students advanced to the abstract level and learned to write mathematical equations and calculate the solutions. It was determined that students improved their problem-solving performance significantly as compared to their baseline measures on both representing and solving relational algebraic word problems.

Moreover. two students transferred concrete representations to semiconcrete representations. Subjects not only met criterion, but also generalized to other persons, settings, and tasks. For example. Huntington (1994) noted. "Subject 3 volunteered that one participant volunteered she had not really understood the meaning of the terms difference, wice, and consecutive. She reported that it had not been enough when teachers had her memorize definitions of the terms. She stated that only after working with the Algebra Lab Gear did she really understand what these words meant" (p. 113).

Similar to the previous study, use of the Algebra Lab Gear was effective for teaching integer numbers and related word problems to students with mild disabilities (Maccini \& Hughes, in press; Maccini \& Ruhl. in press). Students were taught to represent integer operations via a problem-solving strategy, STAR (Maccini. 1998), which involved a general problem-solving strategy for problem representation and solution (Search the word problem. Represent the problem, Answer the problem. Review the answer). Students advanced through three levels of instruction: (a) concrete application (i.e., using the algebra tiles to represent integer problems), (b) semiconcrete application (drawing pictorial representations of the mathematics problems), and (c) abstract application (writing mathematical symbols to represent and solve problems).
For instance, during concrete instruction, students manipulated the tiles to represent word problems involving integer numbers (see Figure 1). Participants in both studies improved their percent strategy use over the instructional phases and significantly improved their problem-solving skills involving integer numbers as compared to baseline measures.

Though use of concrete aids was determined to be effective with students with disabilities, simply using manipulatives when teaching a math concept will not guarantee acquisition of a concept. Marzola (1987) summarized important guidelines when using math manipulatives with students who have disabilities (see Table 2). These include selecting manipulatives that are connected to the concept and to students' developmental level, as well as incorporating a variety of manipulatives, verbal explanations (student and teacher-led), and programming for instructional transitions from concrete to symbolic representation.

\section{Real-World Application and Problem Solving}

In relation to teaching and activating conceptual knowledge. some authorities have suggested contextualizing information in a "real world" context. Embedding the problemsolving information within a real-world context helps students activate their conceptual knowledge when presented with a real-life problem-solving situation (Gagne, Yekovich, \& Yekovich, 1993) and improves student motivation, participation, and generalization (Polloway \& Patton, 1997). As Mercer, Jordan, and Miller (1994) stated, "If mathematical content is to be relevant to learning. it is imperative that it be presented in a real world context. For example, if the instructional content fails to relate $6 y+2 y+$ $6=48$ to a pragmatic word problem, students are memorizing meaningless procedures for obtaining answers" (p. 300). Teacher quotes from the present study also reflect the importance of contextualized learning ("I incorporate fun activities such as timing a wave, weighing bananas, and counting chips in a cookie to acquire data. Students are included in groups and usually have successful experiences with others as they do the activities").

Anchored instruction is one example of embedding problem-solving situations in a real-life situation via interactive videodisc instruction. For example. Bottge and Hasselbring (1993) researched the effects of teaching contextualized word problems $(C P)$ via videodisc instruction versus teaching word problems via teacher-directed instruction (WP) with secondary students with behavioral or learning difficulties from two remedial math courses. Prior to the intervention, students were assessed on their fraction computation skills to determine patterns of error analysis. A 5-day remediation plan involving a videodisc program was developed based on the analysis. Students were reassessed to 
Sample Problem: Suppose in a certain town the high temperature was recorded at $92^{\circ} \mathrm{F}$ and the low temperature was $-13^{\circ} \mathrm{F}$. Find the difference between these temperatures. [CSA story lines also include yardage gains and losses during a football game, and elevation differences]

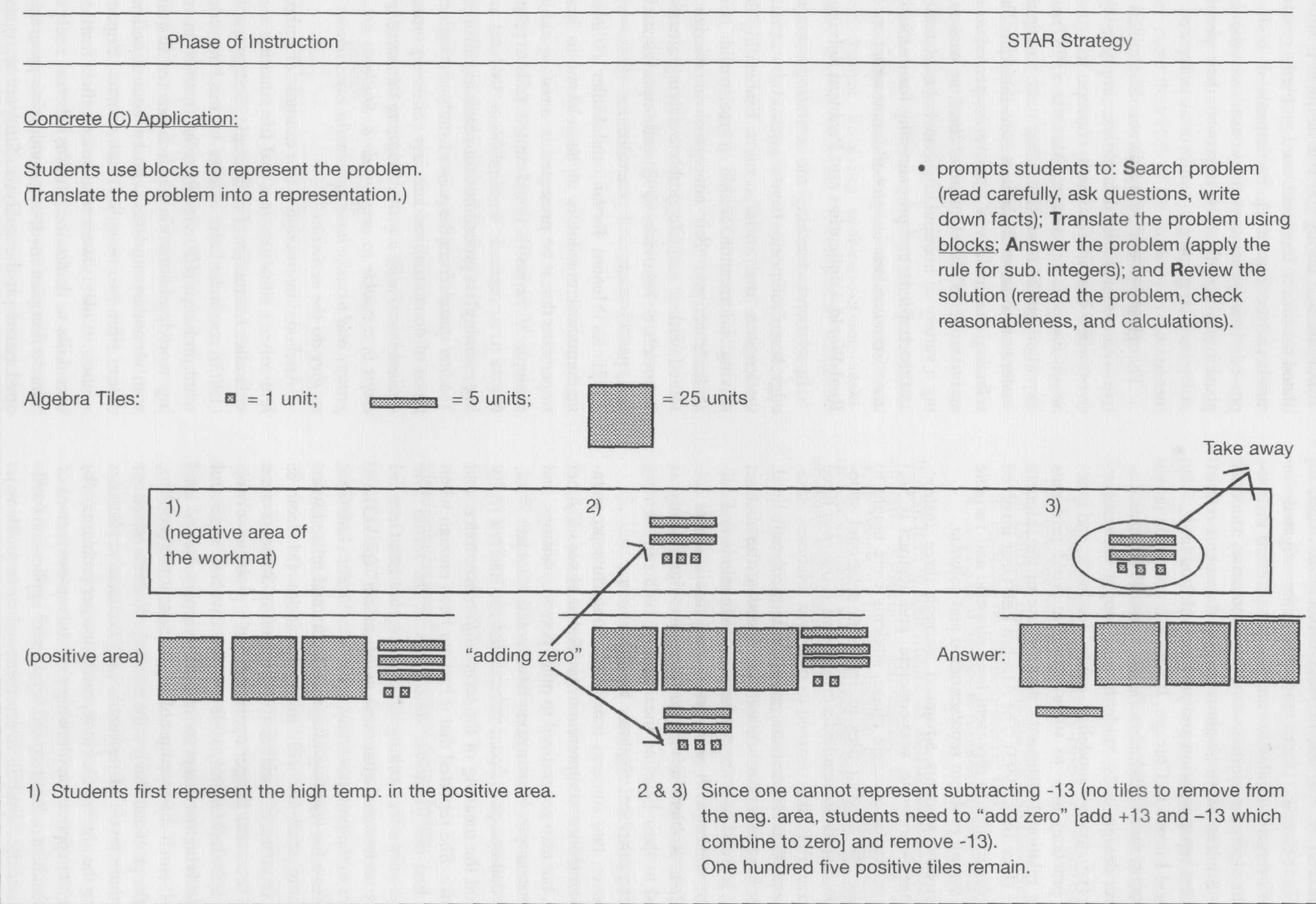

Figure 1

Sample Problem Using Concrete Representation 
determine their level of improvement and preparation for the intervention. Students then were matched by test scores and assigned to either the CP condition or the WP condition. The CP condition included a videodisc program depicting a real-life problem-solving task involving the application of fraction skills and other math tasks to building a cage for a pet.

The researchers determined that students in both groups significantly improved their math performance on a contextualized posttest measure; however, students in the CP condition generalized to another videodisc problem-solving task requiring different math skills than the videodisc problem-solving task presented during instruction. As Bottge and Hasselbring (1993) stated, "CP students who had successfully solved the transfer problem did not narrow their focus only to fractions and measurement, but they seemed to view the problem as a more global representation of how problems naturally occur in real-life settings" (p. 565).

In addition to improving generalization to other math tasks, providing real-life application improves students' ontask behaviors. For example. McWhirter and Bloom (1994) examined the effects of a math curriculum involving a classroom-based business and assessed on-task behavior. Three students with ED participated in the single-subject study within a self-contained classroom. Students learned how to run a business. making and selling wood baskets for holidays. The math curriculum included application of basic math facts for determining overall costs, time cards, receipts, and payroll. As compared to baseline measures, the researchers found that students' overall attention-to-task improved when the intervention was in effect.

\section{ADAPTATIONS AND PROVISIONS BASED ON INDIVIDUALIZED EDUCATION PILANS}

With the inception of the Education for All Handicapped Children Act of 1975, the importance of individualized educational programming for students with disabilities was realized. Since 1975. the prevalent view relates teacher adaptations to student academic success (Corno \& Snow, 1986). The nature of instructional adaptations involves teacher judgment, via formal and informal assessment, resulting in variations and adjustments in teaching strategies and goals (Fuchs, Fuchs, Phillips, \& Simmons, 1993). The continued necessity of adaptations for students with LD and ED in light of the current popularity of the NCTM Standards cannot be overemphasized. A common concern with the Standards is the lack of attention given to students with special and diverse needs (Hofmeister. 1993; Hutchinson, 1993; Mercer, Harris, \& Miller, 1993). Given the lack of specific guidelines for students with special needs, it is important to identify ways in which teachers currently adapt the
Standards within the context of IEPs for students with LD and ED.

Teacher responses to the question addressing typical adaptations and provisions based on IEPs for students with LD and ED were grouped into 18 categories. The most frequent adaptations included: (a) calculator use, (b) assignment modification, (c) behavior management, and (d) extra time on assignments and tests (see Table 1). Overall, the most popular adaptation was the utilization of calculators for students with LD ( $27 \%$ of special educators, $15 \%$ of general educators).

Special educators noted calculators as a tool for students with ED more often than general educators. One possible explanation could be the large percentage of general educators who listed behavior management $(22 \%)$ as a useful adaptation for students with ED, whereas, fewer special educators noted behavior management $(10 \%)$. Factors affecting this difference include: (a) the number of students with ED served in the general education setting without special education support, (b) the relatively large number of students per class in the general education setting, as opposed to resource and self-contained settings, and (c) the percentage of special educators whose responsibilities are confined to exclusionary settings (e.g., self-contained, full time resource) (Gagnon \& Maccini, 2000).

The second most common adaptation recorded for students with LD was modification of assignments $11 \%$ of special educators, $15 \%$ of general educators). Similar to use of calculators, general educators identified assignment modification less often $(7 \%$ ) for students with ED, whereas special educators mentioned it $15 \%$ of the time.

Another noticeable trend was the notation of extra time for assignments and tests as a strategy that general educators ( $12 \%$ for students with LD. $13 \%$ for students with ED) and special educators ( $9 \%$ and $8 \%$, respectively) use.

The following discussion addresses the four most common responses to adaptations based on student IEP goals by general and special educators as they apply the NCTM Standards to the individual needs of students with LD and ED. Examples of specific teacher statements and an evaluation of these statements through a consideration of current literature will follow. In addition, general guidelines for the effective use of the adaptations are included.

\section{Calculators}

The use of calculators was the most prevalent adaptation based on the IEPs of students with LD and ED. Although many of the respondents simply listed "calculators." others developed their explanation to incorporate ways in which this technology was used. Teacher responses involved two primary categories consistent with Etlinger and Ogletree's (1982) view that calculator use has two main functions in 


\section{Table 1 \\ Percent of Teacher Perceptions}

\section{Advantages of Implementing the Standards}

\begin{tabular}{|c|c|c|}
\hline Category & $\begin{array}{c}\text { Percent of General Education } \\
\text { Teachers' Responses }\end{array}$ & $\begin{array}{l}\text { Percent of Special Education } \\
\text { Teachers' Responses }\end{array}$ \\
\hline LD & $\begin{array}{l}\text { 1) Positive effect on student learning and positive } \\
\text { student reaction (19\%) } \\
\text { 2) Promotes conceptual learning via hands-on } \\
\text { activities (16\%) } \\
\text { 3) Promotes a more rigorous math program (higher- } \\
\text { order thinking, critical thinking skills) (14\%) } \\
\text { 4) Promotes connections between math and the } \\
\text { real-world ( } 13 \%)\end{array}$ & $\begin{array}{l}\text { 1) Preparation for school/state requirements and } \\
\text { life beyond school ( } 16 \% \text { ) } \\
\text { 2) Promotes conceptual learning and hands-on } \\
\text { activities ( } 11 \%) \\
\text { 3) Equal opportunity among general and special } \\
\text { education students }(11 \%)\end{array}$ \\
\hline ED & $\begin{array}{l}\text { 1) Promotes connections between math and the } \\
\text { real-world }(17 \%) \\
\text { 2) Positive effect on student learning and positive } \\
\text { student reaction ( } 15 \%) \\
\text { 3) Promotes conceptual learning and hands-on } \\
\text { activities }(12 \%)\end{array}$ & $\begin{array}{l}\text { 1) Preparation for school/state requirements and } \\
\text { life beyond school ( } 26 \% \text { ) } \\
\text { 2) Promotes a more rigorous math program } \\
\text { (higher-order thinking, critical thinking skills) } \\
(13 \%) \\
\text { 3) Promotes conceptual learning/hands-on } \\
\text { activities ( } 11 \%) \\
\text { 4) Equal opportunity among general and special } \\
\text { education students }(11 \%)\end{array}$ \\
\hline
\end{tabular}

Specific Instructional Approaches/Methods Teachers use to Implement the Goals of the NCTM Standards:

LD 1) Manipulatives (19\%)
2) Cooperative Groups (17\%)
3) Effective Instruction (16\%)

ED
1) Cooperative Groups (16\%)
2) Effective Instruction (15\%)
3) Manipulatives (13\%)

1) Effective Instruction (18\%)

2) Calculators/Computers (15\%)

3) Manipulatives (12\%)

4) Real-life Application (11\%)

1) Effective Instruction

2) Real-life Application (15\%)

3) Calculators/Computers (13\%)

Typical Adaptations and Provisions Based on Students' IEP:

LD

1) Calculators (15\%)

2) Assignment Modification (15\%)

3) Extra Time for Tests and Activities (12\%)

ED
1) Behavior Management (22\%)
2) Extra Time for Tests and Activities (13\%)
3) Grouping Practices (13\%)

1) Calculators (27\%)

2) Assignment Modification (11\%)

3) Strategies or Charts (11\%)

1) Calculators $(23 \%)$

2) Assignment Modification (15\%)

3) Testing (10\%)

4) Behavior Management (10\%)

Specific Teaching Methods to Improve Successful Implementation of the Goals of the NCTM Standards:

1) Effective Instruction (21\%)

ED
1) Behavior Management Strategies (27\%)
2) Cooperative Groups (14\%)
3) Effective Instruction (10\%)

1) Effective Instruction (21\%)

2) Manipulatives (18\%)

3) Cooperative Groups (9\%)

1) Effective Instruction (18\%)

2) Strategies (15\%)

3) Manipulatives (13\%) 
Table 2

Guidelines for Using Manipulatives with Students with Disabilities

Guidelines
Select manipulatives that are connected to the
concept and to students' developmental level

Incorporate a variety of manipulatives for concept exploration and attainment

Provide verbal explanations and questions with demonstrations

Provide opportunities for student interaction and explanations

Encourage the use of manipulatives and strategies across settings

Program for transitioning from concrete to symbolic representation

\author{
Suggestions for Addressing Guidelines
}

- Choose manipulatives that clearly illustrate the concept during initial concept exploration to help students connect the objects to the concept and then advance to more abstract representations.

- Illustrate the concept via multiple representations to aid student generalization. For example, after students are familiar with adding integer numbers via color-coded chips, introduce the concept using algebra tiles.

- Incorporate teacher-directed verbal explanations while presenting a concept via manipulatives. Also include self-questions and verbal explanations to improve students' self-monitoring strategies.

- Encourage student participation (opportunities to use manipulatives).

- Monitor student performance as students manipulate objects, explain, and write down their problem-solving steps.

Provide corrective and positive feedback as needed.

- Organize a box of materials (e.g., strategy or cue cards, calculators, algebra tiles) that students can use across settings, such as resource and general math class).

- Incorporate a graduated instructional sequence when teaching a concept: (1) concrete application (i.e., students manipulate objects, such as algebra tiles, to illustrate positive and negative quantities);

(2) semiconcrete application (i.e., use pictorial displays to represent the concept, such as drawing pictures of the algebra tiles to illustrate integer numbers); and (3) abstract application (i.e., incorporate numerical representations, such as $-3+4=$ ).

- Use "portable packets" involving a box or carton of manipulative materials (e.g., cue cards of strategy steps or examples of problems to serve as models, calculators, tiles) that students can carry to different classes and use as needed.

- Incorporate teacher-directed instruction: (1) model example(s) of the target concept and think-aloud while demonstrating the concept via manipulatives. Write the numerical notation for each example presented; (2) monitor student performance as students think aloud while solving a problem(s) via manipulatives, and have them record numeric notations. Students can use the manipulatives to check their problem-solving steps; (3) fade teacher-assistance gradually until students are able to independently think aloud each step of the process while writing each step and checking for problem solution using manipulatives. 
the classroom. First. the "practical" function refers to the use of calculators to complete tedious calculations, save time, increase student motivation, and decrease math anxiety. Second, the "pedagogical" function relates to similarities between calculators. textbooks, and manipulatives in that each enhances students' understanding and competence in mathematics. These classifications are consistent with the five primary functions of calculators as stated by the NCTM.

Within the practical classification, NCTM (1986) identified the use of calculators to:

- perform tedious computations that arise when working with real data in problem-solving situations

- concentrate on the problem-solving process rather than calculations associated with problems

- gain access to mathematics beyond their level of computational skill.

In addition, the pedagogical function coincides with two other uses identified by NCTM (1986):

- to explore, develop, and reinforce concepts including estimation, computation, approximation, and properties

- to experiment with math ideas and discover patterns.

Clearly, these general headings are not completely distinct. However, they do provide a useful framework with which to consider the teachers' responses to adaptations required within student IEPs.

The most common statement by teachers was simply, "Use of calculators." The remainder of teacher responses varied across either pedagogical or practical domains with pedagogical uses employed more often. Further, statements on the need for training students to use calculators were common, as was calculator use "Under all circumstances." Teachers considered the affective benefit as one key practical use: "Daily use of calculator[s] to eliminate arithmetic phobia." Use of calculators to increase motivation also has been noted by researchers (Deshler, Ellis, \& Lenz, 1996). Another practical use was saving time through "Use of the calculator to correct work."

Pedagogical functions of calculators centered on their use as an aid to solve problems. ("[Students] use calculators only after attempting to solve problems" and "[Student] use of calculators to help solve problems. but he/she still must show an understanding by listing their steps"). In addition, calculators were perceived as a tool to facilitate learning ("Use of calculators for students who have not acquired basic math facts"; "I allow the use of calculators, but also encourage mental math and paper/pencil math"). Another teacher response, "[Student] use of a calculator or graphing calculator for Algebra II," is consistent with NCTM (1998) and researchers' (Milou, Gambler, \& Moyer, 1997; Demana \& Waits, 1990) beliefs in the use of calculators to enhance learning by helping students to visualize connections between symbolic and graphic solutions.

The other important category of teacher responses is related to teaching students to use calculators: ("Generally if students have a learning disability in mathematics operations. they are given the opportunity to be trained on a calculator for the Maryland Functional Math Test and MSPAP (Maryland School Performance Assessment Program)": "I do extensive work with students on how to use the calculator. I use an overhead calculator to assist with VAKT [i.e., visual, auditory, kinesthetic, and tactile learning")]. Similarly, Salend and Hofstetter (1996) asserted the importance of training students to use calculators and the effectiveness of overhead projectors for teaching this skill. The authors described the significance of locating and describing the function of each key to students, as well as providing examples of calculator use. Further, Salend and Hofstetter recommended that students be provided opportunities to practice calculations, including estimation skills and reviewing answers obtained through calculator use.

In addition to training students to use calculators effectively, Advani (1972) determined the positive effects of calculator usage on the achievement and attitudes of adolescents with LD and ED. Students were taught to use calculators to: (a) check answers to computational problems. (b) solve problem-solving tasks, and (c) check grocery receipts. The researchers used a pre- and post-test design and a significant positive effect was observed in student achievement. In addition, the attitude survey indicated a substantial increase in student interest and attitude toward math. Though some concerns exist within the study related to replicability of procedures, the positive trends provide initial support for the use of calculators in the secondary classroom with students identified as having LD and ED.

Based on teacher responses, the literature, and NCTM position statements (1998), the following recommendations for teachers are noted:

1. Model calculator application.

2. Use calculators in computation, problem solving. concept development, pattern recognition. data analysis, and graphing.

3. Integrate calculator use in assessment and evaluation.

4. Remain current with state-of-the-art technology.

5. Explore and develop new ways to use calculators to support instruction and assessment. 


\section{Behavior Management}

Considering the very nature of the ED label, it is logical that many behavioral management adaptations are available for these students. Interestingly, 22\% of general-education teachers and $10 \%$ of special educators noted behavior management as an adaptation based on student IEPs. A review of preliminary quantitative data from teacher responses (Gagnon \& Maccini, 2000) reveals three issues that account for the differing importance of behavior management between general and special education teachers:

1. More than $50 \%$ of general educators and $33 \%$ of special educators acknowledged that they had students labeled ED in their class or on their caseload who were included in the general education environment with no special education supports.

2. Of the general educators, $43 \%$ reported having 26-35 students per class and $25 \%$ noted 36 or more students per class.

3. Of the special educators, $55 \%$ noted that they teach either in a self-contained classroom or a full-time resource room, typically situations that have a much lower student-teacher ratio.

Given that a relatively large percentage of general education teachers reported having students with ED who are not receiving special education services and the large general education class sizes, it is reasonable to conclude that the combination of these factors may lead to more behavioral issues for general educators and the subsequent necessity of using behavioral management techniques.

\section{Time-out}

Within the category of behavior management, the use of time-out, seating accommodations, and specific behavior plans (e.g., token economy, behavioral contracting) were the three central adaptations based on student IEPs. Time-out from reinforcement, the most frequent of these responses, is defined as the contingent withdrawal of reinforcing stimuli that maintain the targeted inappropriate behavior (Johnston, 1972). Researchers (Ruhl, 1985; Gast \& Nelson, 1977) have affirmed the effectiveness of time-out procedures for reducing inappropriate behavior of students across a range of ages and settings.

The popularity of time-out is evident from a review of respondents' comments. Teachers noted the usefulness of "Letting them [students] take a time-out when needed" and, "When conflicts arise, students are not cornered or pressured. Students are allowed self-esteem and left alone." Another teacher wrote, "Procedures are in place when a student needs to leave suddenly to stay in control or get back into control." The importance of precise standards and procedures for the effective implementation of time-out has been well documented (Alberto \& Troutman, 1999; Gast \& Nelson, 1977; Nelson \& Rutherford, 1983). In addition, Emmer (1981) stated that "effective management classes" have rules and procedures with clearly established expectations.

An example of effective use of time-out is a study by Webster (1976). The participant was a 13-year-old male in sixth-grade public school. He had difficulties with violent acting-out and a history of psychiatric hospitalization. Physical aggression, operationalized as hitting with hands or objects, kicking, pushing, and biting, were the criterion for placement in time-out. A steady decline in aggressive behavior was observed during the intervention which used timeout, and the behavior was extinguished after 7 weeks. During an 8-week follow up, no incidences transpired that required the use of time-out.

In addition to decreasing aggressive behavior, time-out provides an opportunity for students and teachers to disengage from power struggles. The likelihood of these instances and student defiance of authority increase with adolescents (Mercer \& Mercer, 1998) and are common with many students with ED. Effective use of time-out, however, requires that the classroom be sufficiently positive and reinforcing for the student. If the student views the classroom environment negatively, time-out may serve as a reinforcer (Plummer, Baer, \& LeBlanc, 1977).

Sprick (1985) identified seven criterion for establishing effective use of time-out within the classroom:

1. Set up a place to isolate a student within the classroom.

2. Specify any behavior that will result in the classroom isolation.

3. Determine the length of time the student will stay in isolation once he/she is in control.

4. Establish procedures with the student prior to implementation.

5. Discuss the procedures to use if the student refuses to go to the isolation area.

6. Reinforce the student for appropriate behavior [although not while in time-out].

7. Evaluate the effectiveness of your consequence and reinforcement procedures. (pp. 107-109)

In addition to these guidelines, current laws and ethical considerations should be observed.

Teachers also might consider arranging for a quiet place for the student to take a time-out with another teacher, librarian, or other school personnel (British Columbia Ministry of Education, 1996). Similarly, specific criterion and an agreed-upon time frame are essential. In addition, if students begin to misuse this option, a provision can be added for the student to make up work that is missed. 


\section{Preferential Seating}

Teachers identified use of preferential seating as another adaptation based on students" IEPs. Classroom seating has been shown to be an important variable in the behavior of students with ED (Wheldall \& Lam, 1987). Further, Walker (1981) asserted the physical organization of a class can enhance or inhibit teacher attempts to implement each student's IEP. Respondents to the current study wrote general comments ("seating arrangement"), as well as identifying the specific use of isolated seating ("I may have them sit isolated from the rest of the group so they can focus," "sitting in the front of the class," "I try to place those students in the front with me to keep [them] focused").

Placing students in the front of the class may serve dual purposes: (a) maintaining proximity between the teacher and students with ED, and (b) facilitating attention to task. Proximity between teacher and student, defined as a distance of 3 feet or less (Etscheidt, Stainback, \& Stainback, 1984: Van Houten, Nau, MacKenzie-Keating, Sameoto, \& Colavecchia. 1982), may result in the discontinuation of inappropriate behavior and aid in the reduction of student anxiety and frustration (Walker \& Shea, 1999). A study by Fifer (1986) exemplifies the positive effects of teacher proximity in a secondary mathematics classroom. Reduction of inappropriate behavior throughout the class was observed in classrooms where teachers circulated around the room. In contrast. a high incidence of inappropriate behaviors was observed when teachers circulated the least (Fifer, 1986). Further, Weinstein (1979) determined that students seated in the front of the room had a more positive attitude and participated more in class activities than students seated in the back of the room.

One form of isolated seating is the use of study carrels. These may function as private work areas and serve as a physical boundary, reducing stimulation for easily distracted students (Gallagher, 1995). In addition, this approach to seating may provide greater personal space that aggressive adolescents may require (Newman \& Pollack, 1973).

Although decisions relating to the physical arrangement of the classroom and student seating depend upon the instructional goals and extent of interaction desired, general recommendations do exist. Alberto and Troutman (1999) synthesized information from researchers (Gallagher, 1995; Haring \& Phillips. 1962; Hewett \& Taylor, 1980; Stephens, Hartman, \& Lucas, 1978), and the following may be applicable to secondary mathematics classes:

1. Provision for easy teacher observation of all students

2. Sufficient physical separation of students to minimize inappropriate behaviors

3. Availability of study carrels. (p. 462)

\section{Behavioral Plans}

The other significant behavioral adaptation noted by respondents was the use of positively focused behavioral plans. Teachers cited the use of "Behavior check sheets and a token economy system" and, "Behavior contracts are used." The use of a token system accompanied by teacher praise has been shown to be effective (Drege \& Beare. 1991), and a procedure utilized commonly by effective teachers (Stallings \& Kaskowitz, 1974).

Systems that specify behavioral criteria and secondary reinforcement (e.g., praise, tokens, or points that can be exchanged for another reinforcer) (Alberto \& Troutman. 1999) can be used to sustain appropriate student behavior. guide students from materialistic to social reinforcers, and provide a practical method of reinforcing appropriate behaviors. An important consideration for the reinforcement of students within the secondary math class is recognition for completion of correct mathematical processes regardless of outcome (Lock, 1996). This approach may promote student effort and concentration on the underlying mathematical concepts and procedures and is a goal of the NCTM Standards. In addition, Blackham and Silberman (1975) identified several guidelines that facilitate the effective implementation of a token system:

1. The target behaviors that earn tokens should be specified clearly.

2. The reinforcers that the tokens are exchanged for must be appealing and available only within the token system.

3. The number of tokens earned must match the effort required for performing the target behavior.

4. The teacher should keep a record of the number of tokens each student and the group earn. This could provide an additional incentive.

5. If response cost (token fines) is used, the conditions under which the tokens are earned and lost must be specified clearly.

6. A scheduled token exchange at the end of the day usually works best.

7. The system should be designed to encourage selfcompetition rather than competition between students.

8. Gradually withdraw material reinforcers and stress activities and events.

9. The system should be simple, functional, and not distracting. (pp. 145-146)

In addition, teachers should plan for eventual fading of the program through increased expectations, increased cost of reinforcers, or increased time between token reinforcement. 


\section{Assignment Modification}

In addition to the use of calculators and behavior management strategies, teachers identified assignment modification as an important adaptation based on students' IEPs. Assignment modification is an essential component of math instruction for students with special needs (Salend. 1994). An increasing number of these students are being served in the general education environment (Fuchs, Fuchs, \& Bishop, 1992), and many are functioning below grade level in mathematics. As student IEPs commonly include assignment modifications, teachers are challenged to integrate modifications with instructional practices relative to the goals of the NCTM Standards.

For example, in grades 5-8, the NCTM Standards (1998) state the necessity of using reading and listening to interpret and evaluate mathematical ideas. Modifications (e.g., reading for students, using visuals or manipulatives) might be necessary for students whose disabilities affect these skills. The teachers in the current study noted three assignment modifications most commonly: (a) adjusted workload, (b) reading information for students, and (c) providing written information/notes or allowing verbal answers.

\section{Adjusted Workload}

Respondents to the present survey noted adjusted workload as a common adaptation for students with LD and ED. Teachers mentioned "adjusted workload," "small number of problems to solve," and "shorter assignments." Salend (1990) supports the adaptation of assignments through a decrease in the number of problems assigned and suggests (Bley \& Thornton, 1981):

1. Reviewing previously mastered skills

2. Dividing a task or worksheet into smaller tasks or sections

3. Using a similar assignment/worksheet format (e.g., standardized spacing. color coding, use of boxes and circles for cueing, listing of procedural steps).

Relatedly. Dunlap et al., (1993) determined that inappropriate student behavior decreases when students are presented with a sequence of shortened assignments versus one long assignment.

\section{Reading}

The teacher's reading of word problems to students was another common adaptation. This type of assignment modification is not surprising given learner characteristics of students with ED and LD. Specifically, secondary students with $\mathrm{ED}$ function an average 3.5 grade equivalent units behind their nonlabeled peers in reading (Coutinho, 1986), and students with LD function an average of 3.1 grade levels below nonlabeled students (Wagner, 1995). Given the emphasis on problem solving in the high school math curriculum (Dossey, Mullis, Lindquist, and Chambers, 1988) in light of the Standards (NCTM. 1989) and the widespread use of textbooks that present concepts in an incomprehensible manner (Elliot \& Wiles, 1980), these students have difficulties reading and solving mathematical word problems.

To support the connection between the two subjects, $\mathrm{Cul}_{-}$ lyer (1988) devised a comparison of structural similarities. Specifically, student success in reading requires proficiency with basic sight words and meaning of vocabulary words. Similarly, success in math necessitates a command of contentspecific sight words (e.g., sum, difference, product) and an understanding of the meaning of these words. Cullyer (1988) also notes the need for a specialized vocabulary for both subjects. This would include abbreviations for reading and comparable abbreviations in math related to measurement.

Respondents to the current study also noted the relationship between reading and math as evidenced by their comments: "I have to read to them the application problems because they get confused and frustrated easily and lose their concentration;" "Reading of word problems, directions etc., on all tests and assignments."

In an attempt to gauge the readability of a commonly used eighth-grade math text, Elliot and Wiles (1980) assessed 91 certified middle/junior high mathematics teachers. The majority held advanced degrees with a mean of 12 years teaching experience. Researchers determined that more than $25 \%$ of the teachers were unable to comprehend a well known mathematical concept (percent) with relative ease within the text. The authors noted that these results could not be accounted for by differences in the participants' sex, degree earned, or experience. The issue of math text readability, then, compounds the math difficulties for students with $L D$ and $E D$.

\section{Writing}

Another challenge for teachers as they attempt to modify assignments for secondary math students with LD and ED is the difficulty that these students experience with writing and notetaking. Given the large amount of information presented to students in a lecture format and through textbook explanations (Lazarus, 1993) beginning in the middle school years, proficiency with notetaking is essential for students' success (Robinson, Braxdale, \& Colson, 1988). A review of available studies (Suritsky \& Hughes, 1991), however, indicates that students often neglect the essential ideas of a lecture within their notes. In addition, the readability of math texts could compound the difficulties with extracting key ideas.

Although respondents to the current study did not delineate the exact writing difficulties that affect student 
performance in the mathematics class, research (Graham, Harris, MacArthur, \& Schwartz, 1991) on students with LD includes factors supporting assignment modification for students with special needs in this academic environment. Three factors are especially relevant and may interfere with students' text production:

1. The physical demands of writing

2. Utilization of ineffective strategies and processes

3. An extensive focus on lower-level skills (e.g.. spelling, punctuation).

Given these known factors, it is comprehensible that teachers identified the importance of modifying written tasks.

Adaptations that respondents of the current study made include: "[I] have students verbally recite their answers to a question while I document word for word their response. This helps them express themselves in an open-ended question"; "Expectations in the written goal are lowered somewhat"; "I sometimes allow oral instead of written answers."

In addition to verbal answers. Polloway and Patton (1993) suggested accepting other modes of response based on student individual needs and IEP's, such as:

1. Use of physical materials (manipulatives)

2. Physical identification of an object or answer

3. Written response

Respondents to the current study also stated their use of teacher-made notes in support of students who have difficulties with written expression and notetaking: "Typed notes/notesheets" and "Teacher made notecards." Researchers Mohr (1995) and Meese (1994) support providing notes to students and reducing the amount of copying expected. Although the exact nature of the notes that the respondents supply to students is not specifically known, guided notetaking has been shown to aid in the accuracy of student notes and retention of material (Heward, 1994). In this procedure, students are given a handout in outline form, on which they provide the missing key words based on the teacher's lecture (Olson \& Platt. 2000). Despite the need for more research involving guided notetaking for secondary mathematics classrooms with students labeled LD and ED, it is a potentially effective adaptation that teachers currently utilize.

Within the topic of assignment modification, discussion has centered on adjusted workload, reading to students, allowing verbal responses, and providing notes to students. These modifications are among those that Meese (1994) noted as effective for students with disabilities:

1. Divide assignments into chunks and have timelines for each chunk.

2. Extend time for completing assignments.
3. Encourage the use of calculators and computers.

4. Allow groups to complete some written assignments.

5. Reduce the amount of copying needed throughout the assignment (e.g., from board, notetaking).

6. Require students to paraphrase an assignment's tasks. (pp.350-351)

In addition to agreement with points 1 and 2 above, Salend (1994) includes reduction in the number of problems assigned to students as another effective modification for students with special needs.

\section{Increased Time for Activities and Tests}

The final adaptation based on student IEPs that the teacher respondents noted was increased time for students with LD and ED to complete assignments and tests. Because students with ED tend to become anxious, stressed, and unable to focus within strict time constraints (Gallagher. 1995) and students with LD often require a great deal of time and energy to complete higher-level math problems (Deshler, Ellis, \& Lenz, 1996), it is understandable that teachers would cite this adaptation. Responses included specific references toward assessment ("Allow extra time on tests") and general statements related to assignments (" $M$ LD students always need extra time to complete work". "Extended time with supervision"; "Unlimited time"). Researchers (Chalmers, 1991; Salend, 1994; Mohr, 1995) also acknowledge the importance of (a) allowing an increase in time to complete assignments for students with special needs and (b) providing additional opportunities for practicing new skills (Peacock Hill Working Group, 1991).

In addition to respondents in the current study. Fuchs. Fuchs, Phillips, and Simmons, (1993) determined that teachers, when asked to generate their own adaptations for fictitious students, favor an increase in practice time. Although the Fuchs et al. (1993) study focused on teachers at both the elementary and middle levels (grades 1-6), it provides an example of the value that teachers place on increased time as an adaptation. Similarly, respondents and researchers recognize the potential benefits of adapting time allowed for students during assessments. The purposes of assessment within the context of the NCTM Standards are noted by Rivera. Taylor, and Bryant (1994-1995):

1. Determining mathematical achievement in comparison to one's peer group

2. Gathering diagnostic information

3. Obtaining information to provide instructional feedback and grading

4. Evaluating program effectiveness. (p. 144)

Clearly, the information garnered through assessment is critical. In light of research (Alley, Deshler, \& Warner. 
1979) indicating that as many as $85 \%$ of students with LD have difficulties taking tests. adaptations become crucial in obtaining the most accurate picture possible of students with special needs. An increase in time to complete assessments is one such provision that researchers (Deshler, Ellis, \& Lenz. 1996) and teacher respondents support.

Although an increase in time allotted to students to complete assignments and tests supports individualization of instruction, an increase in time alone may not provide sufficient adaptation for students with LD and ED. To effectively utilize additional time on a topic, several factors have to be considered. As described previously and synthesized by Deshler, Ellis, and Lenz (1996), five variables are essential for the modification of math curricula leading to enhanced skill acquisition and procedural competence:

1. Provide many examples and nonexamples.

2. Provide practice in discrimination.

3. Provide explicit instruction.

4. Separate confusing elements.

5. Consider parsimony. (p. 330)

Consideration of these five variables allows teachers to focus productively and utilize the increase in time provided to students. For example, Edgarton (1992) found that teachers who implemented the instructional practices set forth in the NCTM Standards required less student seatwork and completion of routine tasks. The authors noted a simultaneous increase in systematically applying previously learned material within newly presented concepts and skills to aid generalization.

\section{TEACHING METHODS TO IMPROVE FUTURE NCTM STANDARDS IMPLEMENTATION}

In addition to specific recommendations for adaptations necessary for implementing the goals of the NCTM Standards and student IEPs, teachers were queried about specific teaching methods they perceive as necessary for improving successful implementation of the Standards with students who have LD and ED. Whereas the intent of the question was to determine practices that teachers perceive as necessary for future implementation of the Standards, rather than recommendations for specific instructional approaches or methods they use currently to implement goals of the NCTM Standards, teacher responses were somewhat similar to the two questions.

For example, teachers perceived "effective teaching" practices as necessary for both current and future practice. Utilizing cooperative or group activities, however, was determined to be the second most frequent response for improving future implementation of the Standards, rather than use of manipulatives or real-life applications as indicated in the previous question. As one teacher noted, "For instruction to be successful in implementing the NCTM Standards, various teaching methods are necessary. Cooperative learning paired with teacher-directed lessons (on concept building) are very important."

Specifically, special education teachers indicated effective teaching components as the most prevalent response for students with LD (21\%) and ED (18\%) for improving implementation of NCTM Standards in the future (see Table 1). Further, general education teachers noted certain components of effective instruction for students with LD (21\%). The majority of general education teacher responses $(27 \%)$. however, addressed behavior management strategies (e.g., proximity control, ignoring inappropriate behavior, being patient, and reducing "down time") for students with ED.

Further, the second most prevalent response by general education teachers involved cooperative learning or grouping practices for students with LD (11\%) and ED (14\%) and the third most prevalent response by special education teachers for students with LD $(9 \%)$. The two most prevalent responses across teachers (general and special educators) and disability categories (ED and LD) were effective teaching practices and cooperative learning/grouping activities. These are discussed below within the context of the goals of the NCTM Standards for teaching students with special needs.

\section{Effective Instruction}

Predominant themes in teacher responses addressed specific teaching methods to improve future implementation of the Standards with students having LD and ED. The responses included components found to be effective for teaching math to students with disabilities, such as (a) repetition and review, (b) small group instruction, and (c) mastery teaching. For example, programming for frequent reviews is important for students with LD as many experience memory deficits because of distractibility and problems concentrating during instruction (Bezuk \& Cegelka, 1995).

As teachers in the current study noted for students with LD: "Repetition of concepts throughout the year is essential. Students forget so quickly that activities must be repeated periodically to help them retain methods and concepts" and, "Continual and varied review and practice of the skills being taught." To help students retain mathematical skills and concepts, Bezuk and Cegelka (1995) recommend: (a) teaching for understanding via conceptual lessons, and (b) programming frequent reviews. As discussed earlier, one method for introducing conceptually oriented lessons involves the graduated instructional sequence-concrete-semiconcreteabstract (CSA) continuum. This ensures problem understanding prior to problem solution, which aids in concept or 
skill acquisition and retention (Huntington, 1994; Maccini \& Huges, in press; Maccini \& Ruhl, in press; Miller, 1996).

In addition, to address frequent reviews, it is recommended that lessons include daily, weekly, and monthly reviews of new information and previously mastered skills or concepts (Good \& Grouws, 1979). For example, Good and Grouws (1979) recommend a: (a) daily review consisting of homework problems and/or mental computation skills for approximately 8 minutes at the beginning of class, four times per week; (b) weekly review focusing on math tasks introduced the previous week for approximately 20 minutes every Monday; and (c) monthly review focusing on math tasks introduced the past month.

In addition to frequent and varied reviews, teachers recommended small-group instruction and mastery learning as effective teaching practices to improve successful implementation of the Standards with students having LD and ED. As Archer, Gleason, and Isaacson (1995) stated, "Small-group instruction translates into more instructional time and significantly more active learning opportunities for all students, typically resulting in increased achievement for each individual" (p. 166). For example, teachers could divide students into heterogeneous groups (small groups consisting of a variety of ability levels) and have students work together on problem-solving tasks, classwork, and/or reviews.

Too, requiring a criterion for student mastery before advancing to a new skill or concept (e.g., $80 \%$ or higher during initial learning and $90 \%$ or higher during independent practice prior to independent work) is effective for students who have special needs. Teachers in the present study noted the importance of student mastery: "Students must be given time to achieve mastery of concepts before being pushed through the curriculum or socially promoted year after year"; and "Teach only one concept per class period - then use time to master concept."

\section{Cooperative Grouping Activities}

Another instructional method that teachers in the current study noted as improving implementation of the Standards with students who have LD and ED involved cooperative or group activities. Teacher responses included: (a) general statements addressing cooperative learning (e.g., "Cooperative teaching and learning"), (b) expert groups (e.g., "Another teaching method that is necessary to improve success is the use of expert groups where students learn from each other"); and (c) peer-tutors or role-models (e.g., "Small group (lab) activities - pair LD student with "good" math student," "Have these students in class or groups with good role models").

Cooperative learning experiences improve students' ontask behaviors, academic skills, social skills (help one another and receive assistance), and experience in working toward group goals or rewards. Slavin (1983) determined that for cooperative learning experiences to be effective, students must be held accountable within the groups (i.e., individual accountability) and there must be a group goal for the students to work toward. This can be particularly beneficial with students who experience academic and social deficits, such as students with LD and ED. For example, in a review of peer-tutoring interventions for students with BD, researchers concluded that, overall, tutees and tutors benefit socially and academically from these interactions (Scruggs, Mastropieri, \& Richter, 1985).

In one investigation, Franca, Kerr, Reitz, and Lambert (1990) determined that a peer-tutoring intervention improved the academic and social skills of eight middle-school students with EBD. Students worked in dyads (tutee and tutor) during 15-minute tutoring sessions on fraction concepts and skills. Prior to teaching, tutors were trained to solve the problems, provide step-by-step procedures for problem representation, correct errors, and provide positive reinforcement. Researchers determined that the tutor and tutees improved their fraction skills (decreased error rates. increased rate of correct responses), attitude toward mathematics, and social skills within the dyads.

Another effective grouping approach in mathematics involves working with peer partners (Archer. Gleason. Englert, \& Isaacson, 1995). As one teacher in the current study noted, "Peer tutoring, coaching, hang student explain methods to other students." For example, students work together in pairs on an assignment/worksheet and provide peer assistance via the following steps (Archer et al., 1995):

1. Students solve the first problem independently.

2. Students check their respective answers with a key.

3. If one student errs, the other student illustrates how to solve the problem.

4. Students ask the instructor if they both erred.

These approaches are essential given the rigor of the NCTM Standards and the difficulty that students with LD and ED have with higher-order math tasks.

\section{CONCLUSIONS AND IMPLICATIONS FOR FUTURE PRACTICE}

Having researched the instructional supports and adaptations that teachers perceive as effective for teaching math to secondary students with LD and ED in light of the Standards and the literature, the second author was reminded of his eighth grade son's (Walter's) experience in pre-algebra and algebra within a progressive school district in the Northeast:

Despite the high reputation of the school district,

I was dismayed by the lack of recognition and 
implementation of the goals of the NCTM Standards in my son's math class. All too often, Walter came home with assignments that lacked real world connection, such as solving for an unknown variable or creating $Z$ tables, and his homework was either too simple or reviewed skills that he had previously mastered. Walter also acknowledged that during an accelerated summer program, in preparation for Algebra 1, no new skills were introduced and this affected his motivation to stay on-task. Further, Walter and I reviewed his present Algebra textbook and determined that he could easily pass the first three chapter tests $(24 \%$ of the text) based solely on his previous year's work in pre-algebra.

It is unfortunate that many of Walter's experiences are similar to those of both authors in algebra more than 20 years ago. We hope that some of the noted guidelines outlined in the present review will provide a framework for integrating what is known to be effective for teaching students with disabilities relative to teacher perceptions and the goals of the NCTM Standards. We hope that future mathematics instruction for secondary students with LD and ED extend beyond strictly "drill and practice" approaches to incorporate the following teacher recommendations:

1. When designing and implementing lessons for students with disabilities, incorporate elements of effective instruction, such as teaching explicit strategy instruction. teacher modeling, guided and independent practice, monitoring of student performance, using a wide range of examples and nonexamples, separating potentially confusing terms, and cumulative reviews

2. Select manipulatives related to the target concept or skill and students" level of functioning. Incorporate a variety of manipulatives with student- and teacher-led verbal explanations to illustrate and explain mathematical concepts. In addition, program for transitions from use of concrete manipulatives to abstract representations to promote student generalization.

3. Provide lessons and activities that embed mathematics in real-world situations to foster student understanding of mathematics and promote generalization beyond the classroom.

4. Integrate calculators within instruction and assessment activities via teacher-directed and more discovery-based approaches. Keep current on state-of-theart technological advances and their classroom application.

5. Individualize mathematics instruction through adjusted workload and modifications based on students" reading (e.g., reading to students) and writing (e.g.. guided notetaking, oral responses to questions) skills.

6. Implement positive, pro-active, and consistent behavioral management strategies including time-out, token economies and contracts, and preferential seating to provide specific guidelines for motivating students and encouraging appropriate behavior within mathematics class.

7. Provide additional time for students to complete mathematics assignments and assessments. Consider instructional design variables to provide enhanced skill acquisition and procedural competence.

8. Provide opportunities for students to work in cooperative and group activities to promote positive social skills and concept/skill acquisition and retention.

Teachers have a continuing challenge to help students to become better problem solvers, reason mathematically, value math, become more confident in their ability to do mathematics, and communicate mathematically. This review highlights teacher perceptions of strategies and modifications determined to be effective when teaching math to secondary students with LD and ED in light of the goals of the NCTM Standards. The specific recommendations developed based on these findings provide an initial framework through which the goals may be realized. The importance of student learning extends beyond the classroom and includes affective benefits. As one teacher noted regarding the advantages of implementing the Standards with students who have special needs: "They feel successful in math, something many of these students have not felt in many years."

\section{REFERENCES}

Advani. K. (1972). The effect of the use of desk calculators on achierement and attitude of children with learning and heha'ior problems (research report). Paper presented at 14 th annual conference of Ontario Educational Research Council. Toronto.

Alberto, P. A.. \& Troutman, A. C. (1999). Applied behavior analssis for teachers (pp. 462-484). Upper Saddle, NJ: Merrill.

Algozzine. B., O'Shea. D. J., Crews, W. B.. \& Stoddard K. (1987). Analysis of mathematics competence of learning disabled adolescents. Journul of Special Education, 21,97-107.

Alley. G. R. Deshler, D. D.. \& Warner, M. M. (1979). Identification of learning disabled adolescents: A Bayesian approach. Leaming Disability Quarterl; 2(2). 76-83.

Archer, A. L. Gleason. M. M., \& Isaacson. S. (1995). Effective instructional delivery. In P. T. Cegelka \& W. H. Berdine. Effective instruction for students with learning difficulties (pp. 161-194). Boston: Allyn \& Bacon.

Archer. A. L.. Gleason. M. M.. Englert. C. S.. \& Isaacson. S. (19950. Meeting individual instructional needs. In P. T. Cegelka \& W. H. Berdin. Effective instruction for students with leaming difficulties (pp. 195-225). Boston: Allyn and Bacon.

Bernstein. B. (1997). Message and meaning: The third international math and science study. Eductional Horizons, 76(1), 23-27. 
Bezuk, N. S.. \& Cegelka. P. T. (1995). Etfective mathematics instruction for all students. In P. T. Cegelka \& W. H. Berdine. Effective instruction for students with leciming difficutties (pp. 345-384). Boston: Allyn \& Bacon.

Blackham. G. J., \& Silberman. A. (1975). Modifications of child and adelescent behavioy (2nd ed. pp. 145-146). Belmont. CA: Wadsworth Publishing Company.

Bley, N. S., \& Thornton. C. A. (1981). Teaching mathematics to the learning disabled (pp. 1-34). Rockville. MD: Aspen Systems.

Bos. C. S., \& Vaughn, S. (1994). Strategies for teaching students with leam ing and behavior problems (3rd ed. I. Boston. MA: Allyn \& Bacon.

Bottge. B.. \& Hasselbring. T. S. (1993). A comparison of two approaches for teaching complex. authentic mathematics problems to adolescents in remedial math classes. Exceptional Children. 59, 556-566.

Brian, T., Bay, M.. Lopez-Reyna, N.. Donahue, M. (1991). Characteristics of students with leaming disabilities: A summary of the extant database and its implications for educational programs. In J. W. Lloyd, N. Nirbhay. \& A. C. Repp (Eds.). The regular education initiative: Alternative perspectives on concepts, issues. and models (pp. 113-131). Sycamore. IL: Sycamore.

British Columbia Ministry of Education. Special Education Branch. (1996). Teaching students with leaming and behatioral differences: A resource guide for teachers (pp. 1-42). (ERIC Document Reproduction Service No. ED 414712 ).

Cawley, J. F., \& Miller, J. H. (1989). Cross-sectional comparisons of the mathematical performance of children with learning disabilities: Are we on the right track toward comprehensive programming? Joumat of Leaming Disabilities, 22, 250-259

Cawley. J.F. \& Webster. R.E. (1981). Reading and behavior disorders. In G. Brown. R. L. McDowell. \& J. Smith (Eds.), Educating adolescents with behavior disorders. Columbus, $\mathrm{OH}$ : Merrill.

Chalmers. L. (1991). Classroom moditications for the mainstreamed student with mild handicaps. Intervention in School and Clinic, 27, $40-42,51$

Chard, D. J. \& Kameenui. E. J. (1995). Mathematics instruction for students with diverse learning needs: Heeding the message of the cheshire cat. Focus on Learning Problems in Mathematics, 17. 24-38.

Corno, L.. \& Snow, R. E. (1986). Adapting teaching to differences among individual leaners. In M. Wittrock (Ed.), Third handbook of research on teaching (pp. 605-629). New York: Macmillan.

Coutinho, M. J. (1986). Reading achievement of students identified behaviorally disordered at the secondary level. Behavioral Disorders, /1 $200-207$.

Cullyer, R. C. (1988). Reading and math go hand in hand. Reading Improvement. 25, 189-195.

Demana. F. \& Waits. B. K. (1990). Enhancing mathematics teaching and learning through technology: In T. J. Cooney \& R. Hirsch (Eds.). Teaching and learning mathematics in the 1990's (pp. 212-222). Reston. VA: National Council Teachers of Mathematics.

Deshler, D. D., Ellis, E. S.. \& Lenz. B. K. (1996). Teaching adolescents with learning disabilities: Strategies and methods (2d ed., pp. 315-367). Denver: Love Publishing.

Dossey. J.. Mullis. I., Lindquist, M., \& Chambers, D. (1988). The mathematics report card: Are we measuring up? Princeton, NJ: ETS.

Drege. P. \& Beare, P. L. (1991). The effect of a token reinforcement system with a time-out back-up consequence on the classroom behavior of E/BD students. British Columbia Joumal of Special Education. 1511). $39-46$.

Dunlap. G.. Kern. L., dePerczel, M., Clarke, S., Wilson. D.. Childs, K. E.. White. R. \& Falk. G. D. (1993). Functional analysis of classroom variables for students with emotional and behavioral disorders. Behavioral Disorders, 18. 275-291.
Edgarton. R. T. (1992). A description of the assessment practices of teachers who have begun to implenent the instructional practices suggested in the NCTM standards. Paper presented at annual meeting of American Educational Research Association. San Francisco.

Elliot, P. G., Wiles, C. A. (1980). The print is part of the problem. School Science \& Math, 80, 37-42.

Emmer. T. (1981). Effective management in junior high mathematics classrooms. (ERIC Document Reproduction Service No. ED 206448 ).

Etlinger, L. E., \& Ogeltree, E. J. (1982). Using calculators and microcomputers with exceptional children (ERIC Document Reproduction Service No. ED 215 884).

Etscheidt. S., Stainback. S.. \& Stainback. W. (1984). The effectiveness of teacher proximity as an initial technique of helping pupils control their behavior. Pointer, 28, 33-35.

Fifer. F. L., Jr. (1986). Effective classroom management. Academic Therapx: $21,401-410$.

Fitzmaurice. A. M. (1980). LD teachers" self-ratings on mathematics education compctencies. Learning Disability Quarterly, 3, 90-95.

Franca. V. M., Kerr, M. M., Reitz, A. L.. \& Lambert. D. (1990). Peer tutoring among behaviorally disordered students: Academic and social benefits to tutor and tutee. Education \& Tieatment of Children, I.3. 109-128.

Fuchs. L. S., Fuchs, D., \& Bishop. N. (1992). Teacher planning for students with learning disabilities: Differences between general and special educators. Learning Disabilities Research \& Practice, 7, 120-129.

Fuchs, L.S., Fuchs, D.. Phillips, N.B., \& Simmons, D. (1993). Contextual variables affecting instructional adaptations for difficult-to-teach students. School Psychology Review; 22, (4), 725-743.

Gagne, E. D., Yekovich, C. W., \& Yekovich, F. R. (1993). The cognitive psychology of school leaming (2d ed.). New York: HarperCollins College Publishers.

Gagnon. J. C. \& Maccini. P. (2000). General and special education teachers'perceptions: Teaching mathematics to secondary students with emotional disturbances. Manuscript submitted for publication.

Gallagher. P. A. (1995). Teaching students with behavior disorders: Teth niques and activities for classroom instruction (2d ed.). Denver: Love Publishing.

Gast, D. L., \& Nelson, C. M. (1977). Time out in the classroom: Implica tions for special education. Exceptional Children, 43(7), 461-464.

Good. T. L., \& Grouws, D. A. (1979). The Missouri mathematics effective ness project: An experimental study in fourth-grade classrooms. Jow nal of Educational Psychology: 71, 355-362.

Goodrich. B.. \& Stern, V. W. (1995). Teaching science and mathematics te students with learning disabilities: Challenges and resources. NSF/AAS Invitational Conference on Learning Disabilities and the Teaching of Science and Mathematics, Washington. DC.

Graham. S., Harris, K.R., MacArthur, C.A. \& Schwart2. S. (1991). Writing and writing instruction for students with learning disabilities: Review of a research program. Leaming Disability Quarterly: 14. 89-114.

Haring, N. G.. \& Phillips. E. L. (1962). Educating emotionally disturbed children. New York: McGraw Hill.

Heshusius, L. (1991). Curriculum-based assessment and direct instruction Critical reflections on fundamental assumptions. Exceptional Chitdren, 57, 315-328.

Heward. W. L.. (1994). Three "low-tech" strategies for increasing the frequency of active student response during group instruction. In R. Gardner III, D. M. Sainato, J. O. Cooper, T. E. Heron, W. L. Heward, J. Fshleman, \& T. A. Grossi (Eds.), Behavior analysis in education: Focus. (n) measurably superior instruction (pp. 283-320). Monterey, CA Brooks/Cole Publishing Company.

Hewett. F.M., \& Taylor. F.D. (1980). The emotionally disturhed child in the classrom: The orchestration of success (pp. 214-236). Boston: Allyn and Bacon. 
Hofmeister, A.M. (1993). Elitism and reform in school mathematics. Remedial \& Special Edacation. 14, (6), 8-13.

Huntington. D. J. (1994). Instruction in concrete. semi-concrete, and abstract representation as an aid to the solution of relational problems by adolescents with learning disabilities (Doctoral dissertation, University of Georgia, 1994). Dissertation Abstracts International, 56/02, 512.

Hutchinson, N. L. (1993). Students with disabilities and mathematics education reform-let the dialogue begin. Remedial \& Special Edacation, 14. (6). 20-27.

Hutchinson. N. L. (1993). Effects of cognitive strategy instruction on algebra problems solving of adolescents with learning disabilities. Learning Disability Quarterly: 16, 34-63.

International Association for the Evaluation of Educational Achievement (1996). Mathematics achievement in the middle school vears: LEA's third international mathematics and science study (TIMSS). Chestnut Hill. MA: TIMSS International Study Center. Boston College.

Jetter. A. (1993. February 21). "Mississippi learning." The New York Times Magaine, pp. 288-35, 50, 51, 64, 72.

Jones. R. (1998). Solving problems in math and science education. The American School Board Joumal. 185. (7), 16-19.

Johnston, J. M. (1972). Punishment of human behavior. American Psychologist, 27, 1033-1054

Kelly, B.. \& Carnine, D. (1996). Teaching problem solving strategies for word problems to students with learning disabilities. LD Forum. 21, 5-9.

Kelly, B.. Gersten, R. \& Carnine, D. (1990). Student error patterns as a function of curriculum design: Teaching fractions to remedial high school students and high school students with learning disabilities. Journal of Leaming Disabilities, 1, 23-29.

Lazarus, B. D. (1993). Guided notes: Effects with secondary and post secondary students with mild disabilities. Education \& Treatment of Children, $16(3)$. 272-289.

Lock. R.H. (1996). Adapting mathematics instruction in the general education classroom for students with mathematics disabilities. LD Forum, 2/(2). 19-23.

Maccini. P.. \& Gagnon. J. C. (2000). General and special education teachers'perceptions: Teaching mathematics to secondary students with learning disabilities. Manuscript submitted for publication.

Maccini, P., (1998). Effects of an instructional strategy incorporating concrete problem representation of the introductory algebra performance of secondary students with learning disabilities. Unpublished doctoral dissertation. The Pennsylvania State University, University Park.

Maccini, P.. \& Hughes, C. A. (1997). Mathematics interventions for adolescents with learning disabilities. Learning Disabilities Research \& Practice, 12, 165-176.

Maccini, P. \& Hughes. C. A. (in press). Effects of a Problem-solving Strategy on the Introductory Algebra Performance of Secondary Students with Learning Disabilities._Learning Disabilities Research \& Practice,

Maccini. P., \& Ruhl. K. L. (in press). Effects of a graduated instructional sequence on the algebraic subtraction of integers by secondary students with learning disabilities. Education \& Treatment of Children.

Marzola. E. S. (1987). Using manipulatives in math instruction. Reading Writing, \& Learning Disabilities, 3, 9-20.

McLeod. T. M. \& A Armstrong. S. W. (1982), Learning disabilities in mathematics skill deficits and remedial approaches at the intermediate and secondary level. Leaming Disability Quarterly: 5. 305-311.

McWhirter. C. C. \& Bloom. L. A. (1994). The effects of a student-operated business curriculum on the on-task behavior of students with behavioral disorders. Behational Disorders. 19, 136-141.

Meese. L. (1994). Teaching leamers with mild disabilities: Integrating research and practice (pp. 279-370). Pacific Grove. CA: Brooks/Cole Publishing Company.
Mercer, C. D.. Harris, C. \& Miller, S. P. (1993). Reforming reforms in mathematics, Remedial \& Special Edacation, 14, 14-19.

Mercer, C. D., Jordan, L., \& Miller, S. P. (1994). Implications of constructivism for teaching math to students with moderate to mild disabilities. Jounal of Special Edacation, 28, 290-306.

Mercer, C.D. \& Mercer, A.R. (1998). Teaching students with learning problems (5th ed.. pp. 17/-225). Upper Saddle. NJ: Merrill.

Miller, S. P. (1996). Perspectives on mathematics instruction. In D. D. Deshler, E. S. Ellis, \& B. K. Lenz, Teaching adolescents with learning disabilities: Strategies and methods (2d ed., pp. 313-367). Denver: Love Publishing.

Milou. E.. Gambler, E. D.. \& Moyer. T. O. (1997). Using the griphing calculator in the classroom: Helping students solve the "unsolvable". (ERIC Document Reproduction Service No. ED 223 111).

Mohr. L. L. (1995). Teaching diverse learners in inclusive settings: Steps for adapting instruction. Paper presented at annual international convention of Council for Exceptional Children. Indianapolis, IN.

Moore, L. J., \& Carnine, D. (1989). Evaluating curriculum design in the context of active teaching. Remedial \& Special Education, 10. 28-37.

National Center for Educational Statistics (1997). NAEP 1996 mathematics report card for the nation and states: Findings from the national assessment of educational progress [On-line]. Available: htp://nces.ed.gov/pubsearch/pubsinfo. asp? ?pubid $=97488$.

National Council of Teachers of Mathematics (NCTM) (1986). Position statement of calculator usage. Reston. VA. National Council of Teachers of mathematics.

National Council of Teachers of Mathematics (NCTM) (1989). Cumiculum and evaluation standards for school mathematics. Reston, VA: Author.

National Council of Teachers of Mathematics (NCTM) (1991). Professional standards for teaching mathematics. Reston, VA: Author.

National Council of Teachers of Mathematics (NCTM) (1995). Assessment standards for school mathematics. Reston. VA: Author.

National Council of Teachers of Mathematics (NCTM) (1998). NCTM position statement [On-line]. Available: Huwnctm.org.

Nelson, C. M., Rutherford. R. B. (1983). Timeout revisited: Guidelines for its use in special education. Exceptional Children Quarterly, 3. (4). $56-67$.

Newman, R.. \& Pollack. D. (1973). Proxemics in deviant adolescents. Journal of Consulting \& Clinical Psychology; 40, 6-8.

Olson. J. L.. \& Platt, J. M. (1996). Teaching children and adolescents with special needs (3d ed.). Upper Saddle, NJ: Prentice-Hall.

Parmar, R. S. \& Cawley, J. F. (1995). Mathematics curricula framework: Goals for general and special education. Focus on Learning Problems in Mathematics, $17,50-66$.

Peacock Hill Working Group (1991). Problems and promises in special education and related services for children and youth with emotional or behavioral disorders. Behavioral Disorders, 16, (4), 299-313.

Picciotto, H. (1990). The algebra lab. Sunnyvale, CA: Creative Publications.

Plummer, S. Baer. D. M., \& Blance. J. M. (1977). Functional considerations in the use of procedural timeout and an effective alternative. Journal of Applied Behavior Analysis, 10,689-705.

Polloway, E. A.. \& Patton, J. R. (1993). Strategies for teaching learners with special needs (5th ed.). New York: Merrill.

Rivera. D. M. (1993). Examining mathematics reform and the implications for students with mathematics disabilities. Remedial and Special Education, 14, 24-27.

Rivera. D.M.. Bryant. B.R. (1992). Mathematics instruction for students with special needs. Intervention in School and Clinic. 28, (21. 71-86.

Robinson, S. M.. Braxdale, C. T.. \& Colson. S. E. (1988). Preparing dysfunctional learners to enter junior high school: A transitional curriculum. In E. L. Meyen. G. A. Vergason, \& R. J.. Whelan (Eds.). Effective 
instructional strategies for exceptional children (pp. 243-258). Denver, CO: Love Publishing Company.

Rosenshine. B.. \& Stevens, R. (1986). Teaching functions, In M. C. Wittrock (Ed.). Handbook of research on teaching ( 3 d ed., pp. 376-391). New York: Macmillan.

Ruhl. K. L. (1985). Handling aggression: Fourteen methods teachers use. Pointer, 29, 30-33.

Salend, S. J. (1990). Effective mainstreaning (pp. 249-281). New York: Macmillan.

Salend, S. J. (1994). Effective mainstreaming: Creating inclusive classrooms ( $2 \mathrm{~d}$ ed., pp. 316-381). New York: Macmillan.

Salend, S. J. \& Hoffstetter, E. (1996). Adapting a problem-solving approach to teaching mathematics to students with mild disabilities. Intervention in School \& Clinic, 31, (4), 209-217.

Scruggs, T. E., Mastropieri, M. A.. \& Richter, L. (1985). Peer tutoring with behaviorally disordered students: Social and academic benefits. Behavioral Disorders, 10, 283-294.

Slavin. R. E. (1983). When does cooperative learning increase student achicvement?' Psychological Bulletin. 94, 429-445.

Sprick, R. S. (1985). Discipline in the secondary classroom: A problem-byproblem sunival guide (pp. 66-110). West Nyack, NY: The Center for Applied Research in Education.

Stallings. J. A., \& Kaskowitz, D. (1974). Follow through classroom observation evaluation 1972-1973. Menlo Park, CA: Stanford Research Institute.

Stephens, T.M., Hartman, A.C.. Lucas, V.H. (1978). Teaching children basic skills: A curriculam handbook. Columbus, $\mathrm{OH}$ : Merrill.

Suritsky, S. K., \& Hughes, C. A. (1991). Benefits of notetaking: Implications for secondary and postsecondary students with learning disabilities. Learning Disability Quarterl, 14, 7-18.

Tarver, S. G. (1996). Direct instruction. In Stainback, W. \& Stainback, S.. Controlersial issues confronting special education: Divergent per spectives (2nd ed.. pp. 143-165). Boston: Allyn \& Bacon.
Thornton, C. A., Langrall, C. W.. \& Jones, G. A. (1997), Mathematics instruction for elementary students with learning disabilities. Journal of Learning Disabilities, $30,142-150$.

Van De Walle. J. (1994). Elementary school mathematics (2d ed.). NY Longman.

Van Houten, R., Nau, P.A., MacKenzie-Keating, S.E., Sameoto, D., \& Colavecchia (1982). An analysis of some variables influencing the effectiveness of reprimands. Journal of Applied Behavior Analysis, 15, $65-83$

Wagner, M. (1995). Outcomes for youth with serious emotional disturbance in secondary school and early adulthood. Future of Children, $5(2)$, $90-113$.

Wagner. M.M.. \& Blackorby, J. (1996). Transition from high school to work or college: How special education students fare. Future of Children, 6(1), 103-120

Walker. S. (1981). Structuring the leaming environment for minorits handicapped students. Washington. DC: National Alliance of Black School Educators. Special Education Programs

Walker, J. E., \& Shea. T. M. (1999). Behavior management: A practical approach for educators (pp. 217-254). Upper Saddle. NJ: Merrill.

Webster, R. E. (1976). A timeout procedure in a public school setting. Psychology in the Schools, 13, 72-76.

Weinstein. C.S. (1979). The physical environment of the school: A review of the research. Review of Educational Research, 49, (4), 577-610.

Wheldall, K., \& Lam, Y.Y. (1987). Rows versus tables. II. The effect of two classroom seating arrangements on classroom disruptive rate, on-task behavior and teacher behavior in three special school classes. Educational Psychology, 7, (4), 303-312. 